\title{
Genetic Variation of Insulin-like Growth Factor II (IGF-II) Gene and its Associations with Growth Traits in European Sea bass (Dicentrarchus labrax)
}

\author{
Emel Ozcan-Gokcek ${ }^{1, *}\left(\mathbb{D}\right.$, Raziye Isik ${ }^{2}$, Bilge Karahan ${ }^{1}$, Kutsal Gamsiz ${ }^{1}$ \\ ${ }^{1}$ Ege University, Faculty of Fisheries, Department of Aquaculture, İzmir, Turkey. \\ ${ }^{2}$ Tekirdağ Namık Kemal University, Faculty of Agriculture, Department of Agricultural Biotechnology, Tekirdağ, Turkey.
}

\section{Article History}

Received 19 July 2019

Accepted 06 January 2020

First Online 07 January 2020

\section{Corresponding Author}

Tel.: +902323115338

E-mail: emel.ozcan.gokcek@ege.edu.tr

\section{Keywords}

IGF-II

Dicentrarchus labrax

SNP

Gene

Growth Traits

\begin{abstract}
Insulin-like growth factor II (IGF-II) is a peptide hormone which plays a crucial role in the growth and metabolic regulations of vertebrates. In this study, we identified single nucleotide polymorphisms on IGF-II gene in the European sea bass (Dicentrarchus labrax) and revealed the potential association between the genotypes of IGF-II gene and growth traits in 150 European sea bass. The polymorphisms were determined using DNA sequencing and PCR-RFLP methods in two different regions of IGF-I/ gene. An AT indel and two SNPs as g.5127711C $>$ G and g.5127731G $>T$ in the intron 2 region, and one SNP as g.5129188C $>$ T in the intron 3 region of IGF-I/ gene in the European sea bass were reported for the first time with this study. Two different genotypes (GG, TG) were observed and the G allele was predominant (65\%) in the IGF-II-Ndel locus. Associations between the genotypes of IGF-II-Ndel locus and body weight and total length were statistically significant $(P<0.05)$. Body weight and total length in each group were higher for GG genotype of IGF-II-Ndel locus $(p<0.05)$. In conclusion, the IGF-II-Ndel locus had a significant effect on the body weight and total length which could be useful for sea bass selection and breeding for marker-assisted selection program.
\end{abstract}

\section{Introduction}

The European sea bass (Dicentrarchus labrax), is a marine teleost fish, distributed along the European coastal area of Atlantic Ocean and Mediterranean Sea. Its intensive exploitation as an aquaculture species has become very common during the last decade and the production is concentrated predominantly in the Mediterranean basin, as gilthead sea bream (Sparus aurata) (Vandeputte, Quillet, \& Chatain, 2012). The European sea bass production has increased $24 \%$ and reached up to 191 thousand tons in the last 5 years. The commercial value of sea bass aquaculture production was approximately 1.1 billion dollars in 2016 (FAO, 2018). European sea bass reaches the market size in 16 -
24 months under the Mediterranean environmental conditions (Rad \& Şen, 2016). Thus, growth rate is the most important trait in the economical aspect of the sea bass production. Havenstein, Ferket, \& Qureshi (2003) reported that farm animal production could be increased by $600 \%$ in the systems integrated with the breeding and genetic technologies. In the last few decades, molecular markers have been utilized to improve economic traits that were required for a fast and effective production (Schlicht et al., 2019). Therefore, using molecular markers in relation to growth traits is an essential step for the success of selective breeding programs for the European sea bass production (Louro et al., 2016). 
Molecular markers aimed to detect genetic variation in terms of candidate genes of known or inferred functions that related to the trait of interest were called quantitative trait locus (QTL) markers (Lynch \& Walsh, 1997; Tao \& Boulding, 2003; Desantis \& Jerry, 2007). QTL loci in the genome controlling specific traits, such as growth-axis, were investigated employing different molecular markers (Juhua et al., 2010). Single nucleotide polymorphisms (SNPs) were widely studied markers to detect the genetic variation in the genome (Vykoukalova, Knoll, Dvorak, \& Cepica, 2006; Berkowicz et al., 2011; Huang et al., 2014).

One of the most predominantly analyzed genes related with growth was IGF-II which had a known regulatory mutation that caused a major QTL effect on $30 \%$ muscle growth in pig (Van Laere et al., 2003; Louro et al., 2019). IGF-Il encoded a peptide hormone with insulin like growth factor, which played an important role in the growth of vertebrates and the regulation of their metabolism (Cornish et al., 2007; Harris \& Westwood, 2012). Various studies revealed associations between IGF-II gene polymorphism and economic traits of pigs, cattle, buffalo and chicken (Li, Wang, Zhao, \& Wang, 2004; Abo-Al-Ela, Abu El-Magd, Abeer, El-Nahas, \& Mansour, 2015; Yan et al., 2015). Radaelli, Patruno, Maccatrozzo, \& Funkenstein (2003) revealed that IGF-II was expressed not only in early embryonic development but also during adult life in fish. In another research, IGFIl gene had both metabolic and myogenic effects in muscle cells of rainbow trout (Oncorhynchus mykiss) (Codina et al., 2008). Terova et al. (2007) found that mitogens of the regions related to IGFI and IGF-II had important role in the growth and development of European sea bass. IGF-II was also known to be an imprinted gene with paternal inherited allele expression in both eutherians and marsupial bi-allelic expression was reported in two live-bearing fishes (Lawton et al., 2005; Louro et al., 2018). Peterson, Small, Waldbieser, \& Bosworth (2008) revealed that the IGF-II mRNA levels were greater in muscle and liver of fast-growing fish compared to slow-growing fish in channel catfish (Ictalurus punctatus). On the contrary, IGF-II expression levels in liver found lower in fast-growing European sea bass compared to slow-growing fish (Louro et al., 2018). In another study, two markers in the IGF-II gene region of a genetically improved farmed male tilapia (Oreochromis niloticus) population were found to be closely related with growth (Juhua et al., 2010). Li et al. (2012) reported significant associations between genotypes and growth traits of largemouth bass (Micropterus salmoides). These findings indicate that IGF-II gene is a good candidate gene for MAS programs to improve fish growth traits.

The aims of the presented study were: (i) to assess polymorphism in the IGF-II gene of the European sea bass (Dicentrarchus labrax), using DNA sequencing and PCR-RFLP methods, and (ii) to test the association between the possible polymorphisms and some growth characteristics that would be used in selective breeding programs.

\section{Materials and Methods}

\section{Sampling and DNA Isolation}

Fish that were hatched at the same time and reared under the same environmental conditions (natural photoperiod in off-shore cages, $15 \mathrm{~kg} / \mathrm{m} 3$ harvest size density) were obtained when they were 24 months old from a fish farm located in Karaburun BayIzmir by a private Fish Processing Factory in Izmir in order to be processed. We sampled 150 individuals from the processing company. Feeding was done with the compound diet commercially produced for sea bass. Fish had been sized until they were $2 \mathrm{~g}$. The body weight (W) and total length (TL) of each sample were measured as a first step and commercial grading (4 groups of different weights) was performed. Sampling of fish was done randomly from the male individuals due to excess of males in culture as a consequence of the environments used in culture, interacting with a complex system where both environmental and genetic factors govern sex determination in sea bass (Vandeputte et al., 2012). Then, muscle tissue samples were taken and stored at $-20^{\circ} \mathrm{C}$ until DNA extraction. Genomic DNA was extracted by using a commercial DNA isolation kit (EURX Gene Matrix Tissue- Bacterial DNA Purification Kit, Poland) according to manufacturer's instructions. The quality and quantity of DNA samples were checked by $1 \%$ agarose gel electrophoresis and evaluated visually and by UV spectrophotometry (MaestroGenNano).

\section{PCR Amplification of IGF-I/ Gene}

The exon and intron 2 regions (900 bp) of IGF-II gene (IGF-II-1) and exon and intron 3 regions ( $374 \mathrm{bp}$ ) of IGF-II gene (IGF-II-2) were amplified by PCR (Table 1). The primer sequences of these two regions were designed based on the Dicentrarchus labrax DNA sequence retrieved from GenBank (Accession number HG916846) (Contig CBXY010013989.1) using PrimerBLAST algorithm (https:// www.ncbi.nlm.nih.gov/tools/primer-blast/), and given in Table 1. For amplification reactions, the $35 \mu \mathrm{L}$ PCR volume contained: $50 \mathrm{ng}$ genomic DNA, $0.5 \mu \mathrm{M}$ of each primer, 1× PCR Buffer $\left(\left(\mathrm{NH}_{4}\right)_{2} \mathrm{SO}_{4}\right), 200 \mu \mathrm{M}$ dNTP, 2.5 $\mathrm{mM} \mathrm{MgCl} 2$ and $1 \mathrm{U}$ of Taq DNA polymerase (Taq DNA Polymerase, Thermo Scientific, US). The cycling protocol was $5 \mathrm{~min}$ at $94^{\circ} \mathrm{C}$ for initial denaturation, 35 cycles of amplification; $94^{\circ} \mathrm{C}$ for $45 \mathrm{~s}, 58-60^{\circ} \mathrm{C}$ annealing for $60 \mathrm{~s}$, $72^{\circ} \mathrm{C}$ for $60 \mathrm{~s}$ and $10 \mathrm{~min}$ at $72^{\circ} \mathrm{C}$ for final extension. Afterwards, the PCR products were checked on $2 \%$ agarose gel using horizontal electrophoresis and the gels were stained using SafeView ${ }^{\mathrm{TM}}$ Classic (Applied Biological Material Inc. Canada). 
Table 1. Primers used to amplify European sea bass IGF-I/ gene

\begin{tabular}{lllc}
\hline Primer Name & Primer Sequence & Annealing Temperature ( $\left.{ }^{\circ} \mathrm{C}\right)$ & Product Size \\
\hline IGF-II-1 & F: 5'-ATGTCTTCGTCCAGTCGTG-3' & 58 & 900 bp \\
& R: 5'-AAAGCAGTGGGTGGGACATAG-3' & & Exon 2 and Intron 2 \\
IGF-II-2 & F: 5'-ACAACAGACGGACCCAGAAC-3' & 60 & 374 bp \\
& R: 5'-CGACAGTCAGCACTTTGCAT-3' & & Exon 3 and Intron 3 \\
\hline
\end{tabular}

\section{Genotyping of SNPs by Restriction Fragment Length Polymorphism (RFLP)}

The selection of the restriction enzymes for RFLP analysis was performed via NEBcutterV2.0 (http://nc2.neb.com/NEBcutter2/) using studied IGF-II gene regions. The PCR products of the IGF-II-1 and IGFII-2 gene regions were digested by Ndel (Thermo Scientific, Cat \# FD0584, Lot \# 00430875) (CA'TATG) and Mboll (Thermo Scientific, Cat \# FD0824, Lot \# 00439340) (GAAGA(N)8') restriction enzymes, respectively according to the protocols recommended by the manufacturer. After digestion, the products were visually checked by agarose gel electrophoresis using 3\% agarose (Prona, EU) gel stained with SafeView ${ }^{\mathrm{TM}}$ Classic (Applied Biological Material Inc. Canada).

\section{Sequence Analysis}

Randomly chosen 15 samples of PCR products (total of 30 samples) from each considered region were sent to a private laboratory for DNA sequencing analysis in order to investigate additional variation of the IGF-II gene regions. PCR products were sequenced by automated capillary electrophoresis system (Applied Biosystems, 3500xL Genetic Analyzer, Thermo Fisher Scientific, UK). The electropherogram were carefully checked by using ChromasPro Version 2.1.8 (Technelysium Pty. Ltd. Australia). Afterwards, the sequences were formed for each sample individually by aligning its forward and reverse sequences and a final data file consisting from consensus sequences for each sample was obtained. Moreover, the trimmed sequence file of IGF-II fragments was analyzed by the MEGA6 software (Molecular Evolutionary Genetics Analysis, version 6.0 (Tamura, Stecher, Peterson, Filipski, \& Kumar, 2013).

\section{Statistical Analysis}

Hardy-Weinberg equilibrium of the population was tested via POPGENE (v.1.32) (Yeh, Yang, \& Boyle, 2000). The association between the genotypes (IGF-II-Ndel locus) and economically important traits such as body weight (W) and total length (TL) in European sea bass was determined (via SPSS Inc. V. 18.0, IBM, Chicago, IL, 2009) according to the General Linear Model and an alpha value of 0.05 was chosen as significance level.

$$
\text { Linear Model I }=\quad Y_{i j}=\mu+B_{i}+G_{j}+e_{i j}
$$

where $Y_{i j}$ represents the body weight $(W)$ and total length (TL); $\mu$ represents the average; $B_{i}$ represents group effect, $G_{j}$ represents the effect of IGF-II genotype and $\mathrm{e}_{\mathrm{ij}}$ is the random error.

\section{Results}

In IGF-II-1 gene region, an AT insertion/deletion was observed in the $389-390^{\text {th }}\left(5127733-5127734^{\text {th }} / A T\right)$ positions (Figure 1) and two more SNP positions were determined based on the sequencing results. $G \rightarrow T$ transversion was observed on the $387^{\text {th }}$ position (g.5127731G $>$ T) and $C \rightarrow G$ transversion was observed on the $367^{\text {th }}$ position (g.5127711C $>\mathrm{G}$ ) in the intron 2 region of IGF-II-1 fragment (Figure 2). Likewise, the sequencing of IGF-II-2 gene region has revealed a $\mathrm{C} \rightarrow \mathrm{T}$ transition on the $169^{\text {th }}$ position (g.5129188 C>T) of the intron 3 of /GFII gene (Figure 3).

Two genotypes were identified in the IGF-II gene with the Ndel restriction enzyme: GG homozygotes (508, 392 bp), TG heterozygotes (900; 508, 392 bp) (Figure 4). According to the Ndel restriction of the IGF-II-1 fragment, among all the samples, 44 individuals had GG genotype and 106 individuals had TG genotype while TT genotype was not observed. The allele frequencies were estimated as 0.35 for $T$ allele and 0.65 for $G$ allele. We have estimated the expected genotype frequencies and tested for the deviation from Hardy-Weinberg equilibrium using Chi-square test, which revealed a significant deviation $(P<0.01)$. These results were given in the Table 2. The RFLP analyze result of IGF-II-2 gene region using Mboll restriction enzyme gave only one haplotype and did not reveal any polymorphism.

\section{The Association between IGF-II/Ndel Genotypes and Growth Traits}

Phenotypic characteristics of the European sea bass individuals were recorded when they were 24 months old. The relationships between the genotypes of IGF-II-Ndel locus and body weight and total length scores were summarized in Table 3. For IGF-II-Ndel locus, a result of the association analysis based on General Linear Model, the observed difference between the groups was significant $(P<0.05)$. The individuals that have GG genotypes, had higher body weight values in 


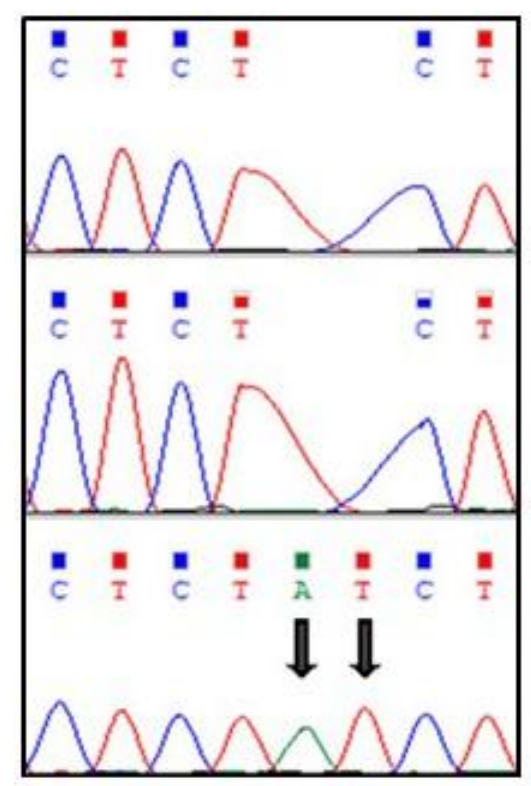

Figure 1. Partial sequence of IGF-I/ gene showing AT insertion\deletion in $2^{\text {ndintron region. }}$

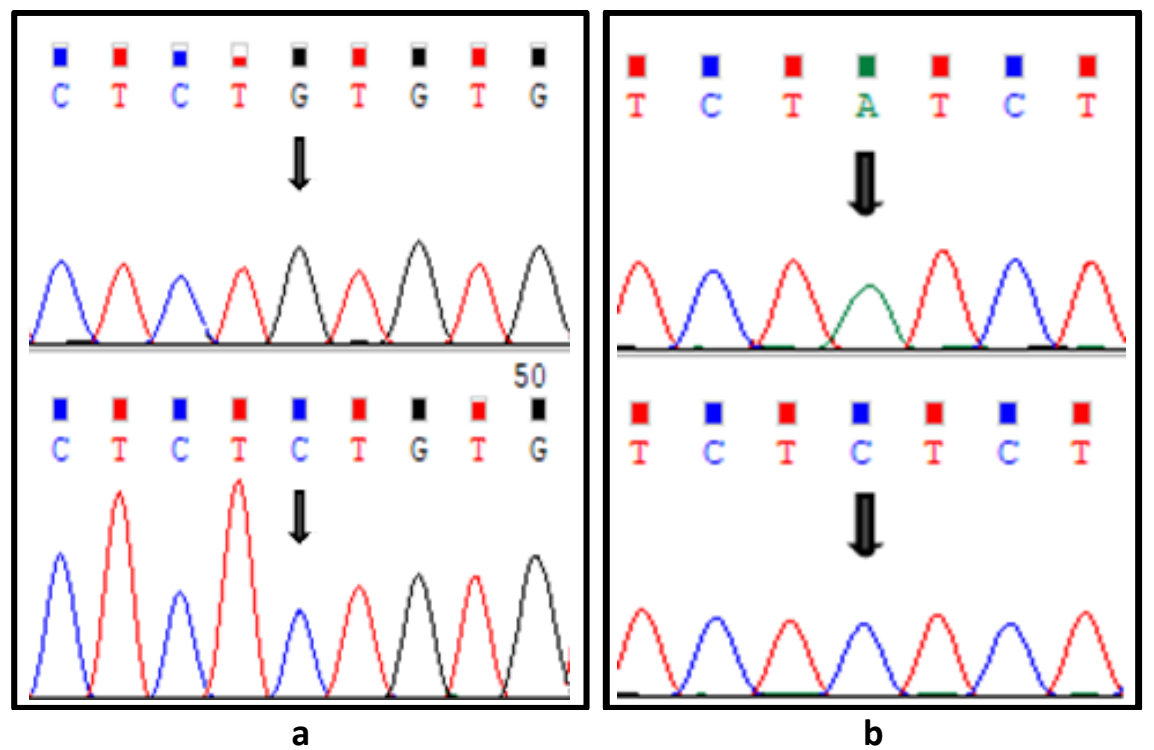

Figure 2. Partial sequence of IGF-II gene showing a) g.5127711C>G (g.367C >G), b) g.5127731G>T (g.387C>A) (antisense sequence) polymorphisms in $2^{\text {nd }}$ intron region.

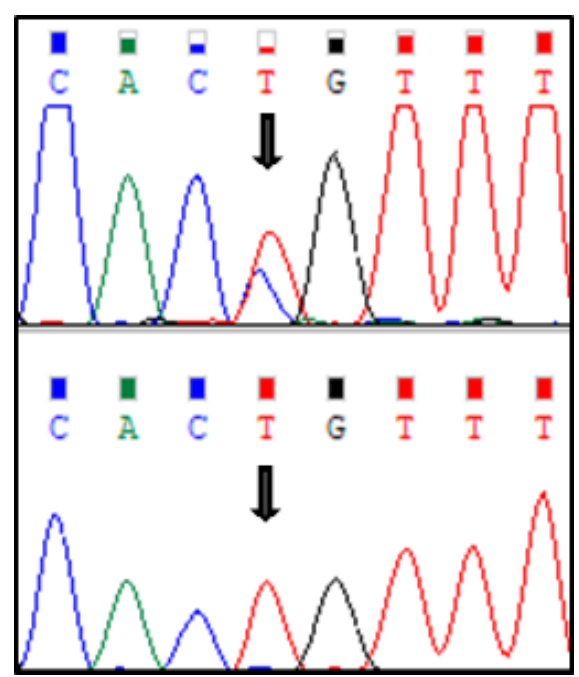

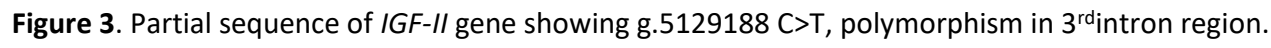




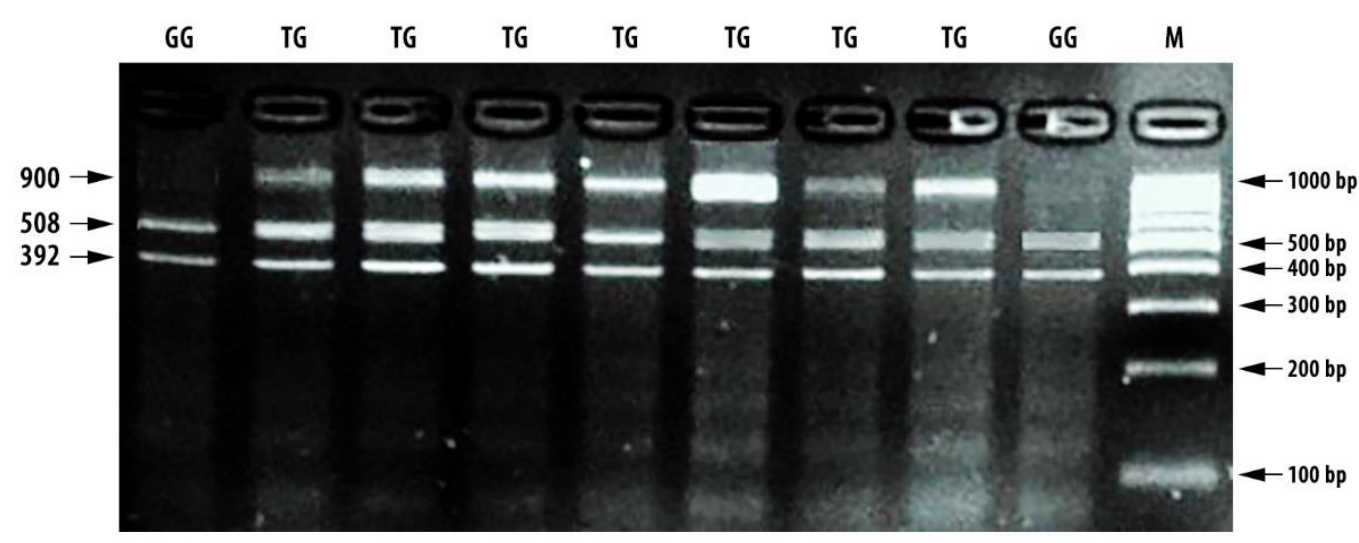

Figure 4. Genotypes of IGF-II-1 fragment of Dicentrarchus labrax, M; Marker, Ndel digestion of the IGF-II-1 fragment, lines 1 and 9 homozygote: GG (508, 392 bp); lane 2-8: TG heterozygote (900; 508, 392 bp).

Table 2. The observed genotypes and allele frequencies obtained from RFLP analysis of IGF-II-2 fragment using Ndel restriction enzyme. The estimated expected genotype frequencies and Chi-square test result are also given

\begin{tabular}{|c|c|c|c|c|c|c|c|}
\hline \multirow[t]{2}{*}{ Locus } & & \multicolumn{3}{|c|}{ IGF-II- Ndel Genotypes } & \multicolumn{2}{|c|}{ Allele Frequency } & \multirow[t]{2}{*}{$x^{2}$} \\
\hline & & GG & TG & TT & $\mathrm{T}$ & G & \\
\hline \multirow[t]{2}{*}{ IGF-II-NdeI } & Obs. & 44 & 106 & 0 & 0.35 & 0.65 & 45.1 \\
\hline & Exp. & 63.4 & 68.3 & 18.4 & & & $(p<0.001)$ \\
\hline
\end{tabular}

Table 3. The association of Ndel polymorphisms of IGF-I/ gene with the body weight and total length in European sea bass

\begin{tabular}{lcccc}
\hline Trait & \multicolumn{2}{c}{ Body Weight $(\mathrm{W})(\mathrm{g})$} & \multicolumn{2}{c}{ Total Length $(\mathrm{TL})(\mathrm{cm})$} \\
\hline Genotype & $\mathrm{GG}$ & $\mathrm{TG}$ & $\mathrm{GG}$ & TG \\
1.Group & $305.512 \pm 12.076^{\mathrm{a}}$ & $296.755 \pm 11.095^{\mathrm{b}}$ & $29.763 \pm 1.304^{\mathrm{a}}$ & $29.446 \pm 0.632^{\mathrm{b}}$ \\
2. Group & $367.304 \pm 9.326^{\mathrm{a}}$ & $358.547 \pm 9.178^{\mathrm{b}}$ & $32.571 \pm 1.350^{\mathrm{a}}$ & $31.894 \pm 0.842^{\mathrm{b}}$ \\
3.Group & $515.792 \pm 10.343^{\mathrm{a}}$ & $507.035 \pm 8.315^{\mathrm{b}}$ & $37.750 \pm 0.954^{\mathrm{a}}$ & $34.870 \pm 0.700^{\mathrm{b}}$ \\
4.Group & $687.425 \pm 16.880^{\mathrm{a}}$ & $678.669 \pm 14.255^{\mathrm{b}}$ & $43.717 \pm 1.458^{\mathrm{a}}$ & $38.406 \pm 0.739^{\mathrm{b}}$ \\
P-value & & & & 0.04 \\
\hline
\end{tabular}

Note. Values in the same row with different superscripts are significantly different $(P<0.05)$.

each group $(P<0.05)$. In addition, the total lengths of fish with GG genotypes for the IGF-II-Ndel were significantly higher than the TG genotype in each group $(P<0.05)$ at the harvest time. These findings suggested that for fish with IGF-II-Ndel locus had a significant effect on body weight and total length which could be useful for sea bass selective breeding programs considering markerassisted selection (MAS).

\section{Discussion}

In this study, we investigated $2^{\text {nd }}, 3^{\text {rd }}$ exon and $2^{\text {nd }}$, $3^{\text {rd }}$ intron of the IGF-II gene and its polymorphism in the European sea bass. An AT insertion \deletion was found in intron 2 region of IFG-II-1 gene. Juhua et al., (2010) also found an insertion in the middle of two intron regions of IGF-II gene of Nile tilapia. The intron regions which have many repetitive sequences and a higher AT content may not be suitable for DNA sequencing by Sanger method. However, NGS (Next Generation Sequencing) technologies can help to improve highthroughput SNP analysis. Besides Taq DNA polymerase and PCR chemicals should be developed specifically for AT/GC rich regions which could help to perform more precise PCR amplifications and sequence analysis.

The two SNPs as g.5127711C >G and g.5127731G >T were determined in the intron 2 region and one SNP as g.5129188T>C was observed in the intron 3 region of IGF-II gene. SNPs in intronic regions may regulate gene expression, especially when they are located close to exon regions (De-Santis \& Jerry, 2007; Tsai, Hamilton, Guy, \& Houston, 2014). The ends of intron regions have an important role in RNA splicing (Fedorova \& Fedorov, 2003). Tao and Boulding (2003) revealed that the presence of a $\mathrm{G}$ nucleotide in the SNP allele at the intron conjunction could effect the growth traits in Arctic charr 
(Salvelinus alpinus). This SNP could cause the differential splicing of mRNA and greater expression of PACAP in fish possessing it. Several studies have shown that SNPs in the intron regions of the growth related genes, had influence on fish growth characteristics e.g. in the farmed Atlantic salmon (Salmo salar) (Tsai et al., 2014) and rainbow trout (Panicz, Zych, \& Grzesiak, 2014). Researches have carried out studies to investigate the associations between IGF-II gene variants with back fat, body weight, fat composition, and other quantitative characteristics in chicken, beef and pigs (Van Laere et al., 2003; Li et al., 2004; Vykoukalova et al., 2006; Zhang, Chen, Li, Lei, \& Xue, 2007). Van Laere et al. (2003) proved a causal relationship between a SNP in intron 3 region of IGF-II gene and a QTL effect in pigs. Intron regions are more polymorphic than exon regions (Tsai et al., 2014). However, only a few researches investigated the relationships between IGF-I/ gene region and growth characteristics in fish. Juhua et al. (2010) determined the association between the IGF-II gene and growth trait in GIFT strain of tilapia and they identified nine polymorphisms in the $1^{\text {st }}, 3^{\text {rd }}$ intron and four silent mutations in the $2^{\text {nd }}, 3^{\text {rd }}$ exon regions. Li et al. (2012) reported four SNPS in the IGF-II gene of largemouth bass. They have not found significant association between genotypes of IGF-II gene and growth traits in largemouth bass but on the other hand they found relationship with two diplotypes and growth traits in IGF-II gene region $(p<0.05)$. Khatab et al. (2014), determined 14 SNPs in IGF-II gene region of large size Nile tilapia but they did not conduct an association study.

Louro et al. (2018) revealed a candidate function of IGF-II in growth regulation of European sea bass. In another study, Louro et al. (2016) found that the sea bass LG6 (linkage group 6) has a high quantitative effect on the growth axis such as IGF-II and leptin. Therefore, in our study we have chosen to identify IGF-II gene located on LG6 (HG916846). We used two different restriction enzymes for genotyping with PCR-RFLP and only one of them was found non-polymorphic. Two different genotypes (GG, TG) were observed and the $G$ allele was predominant for IGF-II-Ndel locus. We think that the absence of TT genotype may be due to the elimination (on sizing) of slow-growing individuals from the population by human during aquaculture process. We found that the IGF-II-Ndel locus had a significant effect on body weight and total length which could be useful for carrying out marker assisted selection (MAS) in a sea bass selective breeding program.

Molecular markers have been used more commonly in the breeding activities to shorten the long and labor-intensive periods of the species taken into production in aquaculture and also to increase the efficiency of the selective breeding program. There are many environmental variance components in aquaculture, due to intensive and time-consuming production process and thus, MAS has a significant potential for identifying individuals with genetically superior growth characteristics (Tao \& Boulding, 2003). Many researches have been carried out to reveal the association between gene polymorphism with economic traits in aquaculture. As a conclusion of this study IGF-II gene is a strong candidate gene for the growth traits in the European sea bass and this result is also supported by the previous studies of other fish species and farm animals. We strongly recommend using this region as a marker in breeding programs planned for sea bass.

\section{Acknowledgements}

The funding of the current research was supported by Scientific Research Projects Coordination Unit of Ege University (Project No: 16-SÜF-025). We thank Evren Koban Baştanlar for her scientific contributions during writing stage of this article.

\section{References}

Abo-Al-Ela, H.G., Abu El-Magd, M., Abeer F., El-Nahas, A.F., \& Mansour, A.A. (2015). Association of a novel SNP in exon 10 of the IGF2 gene with growth traits in Egyptian water buffalo (Bubalus bubalis). Tropical Animal Health and Production, 46 (6), 947-952. https://doi.org/947-952 10.1007/s11250-014-0588-3

Berkowicz, E.W., Magee, D.A., Sikora, K.M., Berry, D.P., Howard, D.J., Mullen, M.P., . . MacHugh, D.E. (2011). Single nucleotide polymorphisms at the imprinted bovine insulin-like growth factor 2 (IGF2) locus are associated with dairy performance in Irish HolsteinFriesian cattle. Journal of dairy research, 78(1), 1-8. https://doi.org/10.1017/S0022029910000567

Codina, M., García de la Serrana, D., Sánchez-Gurmaches, J., Montserrat, N., Chistyakova, O., Navarro, I., \& Gutiérrez, J. (2008). Metabolic and mitogenic effects of IGF-II in rainbow trout (Oncorhynchus mykiss) myocytes in culture and the role of IGF-II in the PI3K/Akt and MAPK signalling pathways. General and Comparative Endocrinology, 157(2) 116-124. https://doi.org/10.1016/j.ygcen.2008.04.009

Cornish, J., Callon, K. E., Bava, U., Watson, M., Xu, X., Lin, Reid, I. R. (2007). Preptin, another peptide product of the pancreatic $\beta$-cell, is osteogenic in vitro and in vivo, American Journal of Physiology-Endocrinology and Metabolism, 292: (1) E117-E122. https://doi.org/10.1152/ajpendo.00642.2005

De-Santis, C., \& Jerry, D. R. (2007). Candidate growth genes in finfish-where should we be looking? Aquaculture, 272, 22-38.

https://doi.org/10.1016/j.aquaculture.2007.08.036

FAO (2018). Food and Agriculture Organization. Fisheries and Aquaculture Department; available at:

http://www.fao.org/fishery/statistics/globalaquaculture-production/query/en, last access: 26 Nov. 2018.

Fedorova, L., \& Fedorov, A. (2003). Introns in gene evolution, Genetica, 118, 123-131.

Harris, L.K., \& Westwood M. (2012). Biology and significance of signalling pathways activated by IGF-II. Growth Factors, 30(1) 1-12. https://doi.org/10.3109/08977194.2011.640325 
Havenstein, G. B., Ferket, P. R., \& Qureshi, M. A. (2003). Carcass composition and yield of 1957 versus 2001 broilers when fed representative 1957 and 2001 broiler diets. Poultry Science, 82(10) 2003, 1509-1518. https://doi.org/10.1093/ps/82.10.1509

Huang, Y.Z., Zhan, Z.Y., Li, X.Y., Wu, S.R., Sun, Y.J., Xue, J., . . Chen, H. (2014). SNP and haplotype analysis reveal IGF2 variants associated with growth traits in Chinese Qinchuan cattle. Molecular biology reports, 41(2), 591598.

Juhua, Y., Xuefeng, C., Jianlin, L., Yongkai, T., Hongxia, L., Pao, X., \& Zaijie, D. (2010). Isolation of IGF2 and association of IGF2 polymorphism with growth trait in genetically improved farmed tilapias, Oreochromis niloticus L. Aquaculture Research, 41(11), e743-e750.

Khatab, S. A., Hemeda, S. A., El-Nahas, A. F., \& Abd El Naby, W. S. H. (2014). Genetic Polymorphism in IGF-II Gene and Its Relationship with Growth Rate in Tilapia Nilotica. Alexandria Journal of Veterinary Sciences, 43, 26-32. https://doi.org/10.5455/ajvs.167827

Lynch, M., \& Walsh, B. (1997). Genetics and Analysis of Quantitative Traits. Sinauer, Sunderland, Massachusetts, p. 980

Lawton, B. R., Sevigny, L., Obergfell, C., Reznick, D., O'Neill, R. J., \& O'Neill, M. J. (2005). Allelic expression of IGF2 in live-bearing, matrotrophic fishes. Development Genes and Evolution, 215(4), 207-212. https://doi.org/10.1007/s00427-004-0463-8

Li, Z., Li, H., Wang, Q., Zhao, J., \& Wang, Y. (2004). The study on correlation analysis of single nucleotide polymorphism of IGF2 gene and body fatness traits in chicken. Agricultural sciences in China, 3(10), 789-794.

Li, X., Bai, J., Hu, Y., Ye, X., Li, S., \& Yu, L. (2012). Genotypes, haploypes and diplotypes of IGF-II SNPs and their association with growth traits in largemouth bass (Micropterus salmonides), Molecular Biology Reports, 39, 4359-4365. https://doi.org/10.1007/s11033-011$1223-2$

Louro, B., Kuhl, H., Tine, M., de Koning, D.J., Batargias, C., Volckaert, F.A.M., Power, D. M. (2016). Characterization and refinement of growth related quantitative trait loci in European sea bass (Dicentrarchus labrax) using a comparative approach, Aquaculture, 455, 8-21. https://doi.org/10.1016/j.aquaculture.2016.01.004

Louro, B., Martins, R.S.T., Pinto, P.I.S., Reinhardt, R., de Koning, D.J., Canario, A.V.M., \& Power, D.M. (2018). SuperSAGE digital expression analysis of differential growth rate in a European sea bass population. Aquaculture and Fisheries, 1-11.

https://doi.org/10.1016/j.aaf.2018.03.001

Louro, B., Martins, R.S.T., Pinto, P.I.S., Reinhardt, R., de Koning, D.J., Canario, A.V.M., ... Power, D.M. (2019). SuperSAGE digital expression analysis of differential growth rate in a European sea bass population. Aquaculture and Fisheries, 4, 17-26. https://doi.org/10.1016/j.aaf.2018.03.001

Panicz, R., Zych, S., \& Grzesiak, W. (2014). A novel polymorphism within intron $b$ of growth hormone gene (GH2) of the rainbow trout, Onchrynchus mykiss. Polish Journal of Environmental Studies, 29(2), 153-160.

Peterson, B.C., Small, B.C., Waldbieser, G.C., \& Bosworth, B.G. (2008). Endocrine Responses of Fast- and Slow-Growing Families of Channel Catfish. North American Journal of Aquaculture, 70, 240-250. https://doi.org/10.1577/A07023.1
Rad, F., \& Şen, I. (2016). Sea bass and sea bream sector overwiew- Turkey. CERES-Climate Change and European Aquatic Resources. Technical Report, (Task 4.2). Mersin, Turkey, $67 \mathrm{pp}$.

Radaelli, G., Patruno, M., Maccatrozzo, L., \& Funkenstein, B. (2003). Expression and cellular localization of insulin-like growth factor-II protein and mRNA in Sparus aurata during development. Journal of Endocrinology, 178, 285-299.

Schlicht, K., Krattenmacher N., Lugert, V., Schulz, C., Thaller, G., \& Tetens J. (2019). Estimation of genetic parameters for growth and carcass traits in turbot (Scophthalmus maximus). Archives of Animal Breeding, 62, 265-273. https://doi.org/10.5194/aab-62-265-2019

Tamura, K., Stecher, G., Peterson, D., Filipski, A., \& Kumar, S. (2013). MEGA6, Molecular Evolutionary Genetics Analysis Version 6.0; http://www.megasoftware.net/. (last accesses: 12 Nov 2018)

Tao, W. J., \& Boulding, E. G. (2003). Associations between single nucleotide polymorphisms in candidate genes and growth rate in Arctic charr (Salvelinus alpinus L.). Heredity, 91, 60-69. https://doi.org/10.1038/sj.hdy.6800281

Terova, G., Rimoldi, S., Chini, V., Gornati, R., Bernardini, G., \& Saroglia, M. (2007). Cloning and expression analysis of insulin-like growth factor I and II in liver and muscle of seabass (Dicentrarchus labrax L.) during long-term fasting and refeeding. Journal of Fish Biology, 70, 219233. https://doi.org/10.1111/j.1095-8649.2007.01402.x

Tsai, H. Y., Hamilton, A., Guy, D. R., \& Houston, R. D. (2014). Single nucleotide polymorphismsin the insulin-like growth factor 1 (IGF1) gene are associated with growth related traits in farmed Atlantic salmon. Animal Genetics, 45, 709-15. https://doi.org/10.1111/age.12202

Van Laere, A. S., Nguyen, M., Braunschweig, M., Nezer, C., Collette, C., Moreau, L., Andersson, L. (2003). A regulatory mutation in IGF2 causes a major QTL effect on muscle growth in the pig. Nature, 425, 832-836. https://doi.org/10.1038/nature02064

Vandeputte, M., Quillet, E., \& Chatain, B. (2012). Are sex ratios in wild European sea bass (Dicentrarchus labrax) populations biased? Aquatic Living Resources, 25, 77-81. https://doi.org/10.1051/alr/2012002

Vincze, T., Posfai, J., \& Roberts, R. J. (2003). NEBcutter: A program to cleave DNA with restriction enzymes. Nucleic Acids Research, 31(13), 3688-91. (last access: 12 January 2018)

Vykoukalova, Z., Knoll, A., Dvorak, J., \& Cepica, S. (2006). New SNPs in the IGF2 gene and association between this gene and backfat thickness and lean meat content in Large White pigs. Journal of Animal Breeding Genetics, 123, 204-207. https://doi.org/10.1111/j.1439-0388.2006.00580.x

Yan, L., Fang, X., Liu, Y., Mauricio, A., Elzo, M. A., Zhang, C., \& Chen, H. (2015). Exploring the genetic variants of insulinlike growth factor II gene and their associations with two production traits in Langshan chicken. Journal of Applied Animal Research, 45(1), 60-63. http://dx.doi.org/10.1080/09712119.2015.1124328

Yeh, F., Yang, R. C., \& Boyle, T. (2000). Popgene (v.1.32), Microsoft Windows-based freeware for Population Genetic Analysis. http://www.ualberta.ca/ fyeh/ Pop32.exe, (last access: 25 Sep 2018) 
Zhang, Z.F., Chen, H., Li, Q.L., Lei, C.Z., \& Xue, K. (2007). Study on the polymorphism in exon 2 of insulin-like growth factor 2 gene and its relationship with several growth traits in Nanyang Cattle. Acta Veterinaria et Zootechnica Sinica, 38, 8-13. https://doi.org/10.1007/s11515-0080099-y 